\title{
Arkadiusz Malkowski
}

Zachodniopomorski Uniwersytet Technologiczny w Szczecinie

e-mail: amalkowski@zut.edu.pl

\section{TURYSTYKA MEDYCZNA W OBSZARACH PRZYGRANICZNYCH NA PRZYKŁADZIE WOJEWÓDZTWA ZACHODNIOPOMORSKIEGO MEDICAL TOURISM IN THE BORDER AREAS ON THE EXAMPLE OF THE WEST POMERANIAN VOIVODESHIP}

DOI: $10.15611 /$ pn.2017.487.15

JEL Classification: I15, F15

Streszczenie: W artykule poruszono problem turystyki medycznej w obszarach peryferyjnych. Celem badań jest przedstawienie problematyki rozwoju turystyki medycznej w regionie przygranicznym. Obszar terytorialny badań stanowiło województwo zachodniopomorskie. W pracy wykorzystano metodę analizy danych źródłowych oraz wyniki badań ankietowych przeprowadzonych przez autora. W artykule pokazano, czym jest turystyka medyczna i jakie są jej przejawy. Przedstawiono potencjał rozwoju tej formy turystyki w obszarze przygranicznym. Wykazano kierunki rozwoju turystyki medycznej oraz uwarunkowania jej rozwoju w tym obszarze. Badania wykazały, że turystyka medyczna jest ważnym czynnikiem rozwoju obszarów przygranicznych. Zmiana funkcji granic, swoboda przemieszczania się ludności oraz zaoferowanie wielu usług medycznych zagranicznym klientom wpłynęło na rozwój tej formy turystyki, która powinna być produktem turystycznym regionu zachodniopomorskiego, stając się istotnym dopełnieniem już realizowanych funkcji turystycznych.

Słowa kluczowe: turystyka medyczna, województwo zachodniopomorskie, obszar przygraniczny, rozwój regionów.

Summary: This article is about medical tourism in peripheral areas. The aim of the study is to present the issues of medical tourism development in the border region. The territorial region of research was the West Pomeranian Voivodeship. The paper used the method of analysis of the source data and the results of surveys conducted by the author. The article shows what medical tourism is and what are its manifestations. The development potential of this form of tourism in the border area was presented. The trends of medical tourism development are shown and the conditions for its development in the border area are pointed out. The research shows that medical tourism is an important factor in the development of cross-border areas. Changing the functions of the borders, freedom of movement of the population and creating a wide range of medical services targeted at foreign clients influenced the development of this form of tourism. Medical tourism should become a tourist product of the West Pomeranian 
region, becoming a significant complement to already implemented tourist functions in the region.

Keywords: medical tourism, Western Pomeranian Voivodeship, border area, region development.

\section{Wstęp}

Problem rozwijania nowych funkcji gospodarki obszarów przygranicznych oraz potrzeba zachowania szerokiego wachlarza ich funkcji społecznych, świadczących o tożsamości społeczności przygranicznej, staje się kluczowy z punktu widzenia potrzeby zapewnienia ludności obszarów podzielonych granicami poprawy standardu życia [Sammel, Prochorowicz, Majewska 2013, s. 101-113].

Model wielofunkcyjnego rozwoju obszarów przygranicznych powinien stać się jednym z podstawowych elementów polityki względem obszarów peryferyjnych w Polsce [Kłodziński, Okuniewski 1993; Kłodziński 1995, s. 11-121; Malkowski 2013, s. 363-372].

Nowa rzeczywistość, w której funkcjonują obszary przygraniczne, jest konsekwencją przemian społeczno-gospodarczych i politycznych, w tym postępującego procesu integracji ze strukturami europejskimi oraz procesu globalizacji gospodarki światowej. W konsekwencji regiony przygraniczne są silnie zróżnicowane pod względem struktury społecznej i ekonomicznej, a także funkcjonalnej. Charakterystyczny dla obszarów pogranicza jest często podkreślany w literaturze ekonomicznej i socjologicznej ich peryferyjny charakter [Przybyła 1995; Miszczuk 2013; Krok 2006, s. 47-65; Malkowski 2011, s. 364-372]. Przezwyciężenie tych negatywnych zjawisk możliwe jest dzięki znalezieniu nowych funkcji gospodarczych i społecznych dla obszarów peryferyjnych.

\section{Cel, zakres i metody badań}

Celem artykułu jest przedstawienie rozważań autora na temat roli, jaką w rozwoju obszarów przygranicznych odgrywać może rozwój usług medycznych, a w szczególności rozwijający się rynek turystyki medycznej. Badania miały na celu zweryfikowanie hipotezy: turystyka medyczna może być ważnym czynnikiem rozwoju obszarów przygranicznych.

Przedstawiono w nim wyniki badań prowadzonych na pograniczu zachodnim Polski w latach 2010-2016 ze szczególnym uwzględnieniem obszaru województwa zachodniopomorskiego. W artykule wykorzystano wyniki badań ankietowych skierowanych do mieszkańców obszarów przygranicznych oraz wywiadu pogłębionego przeprowadzonego w 2016 i 2017 roku w 32 podmiotach świadczących usługi w ramach turystyki medycznej. W pracy wykorzystano metodę analizy danych statystycznych oraz metodę opisową z elementami wnioskowania dedukcyjnego. Prezentację wyników wsparto techniką tabelaryczną oraz graficzną. 


\section{Wielofunkcyjny rozwój obszarów peryferyjnych}

Wielofunkcyjny rozwój jednostek przestrzennych zazwyczaj rozpatrywany jest na dwóch płaszczyznach - przestrzennej i społeczno-gospodarczej. Pierwszy aspekt odnosi się do zagadnień związanych z planowaniem przestrzennym i najczęściej sprowadzany jest do właściwego rozmieszczenia różnorakich form aktywności społeczno-gospodarczej w przestrzeni ekonomicznej. Drugi aspekt dotyczy racjonalnego wykorzystania zasobów, którymi dysponuje każda jednostka terytorialna.

W odniesieniu do obszarów przygranicznych koncepcja wielofunkcyjnego rozwoju nabiera jeszcze większego znaczenia. Potrzeba odejścia od przedstawiania obszarów przygranicznych jako schyłkowych i skazanych na marginalizację związana jest $\mathrm{z}$ dostrzeżeniem unikatowych często walorów tych obszarów i potencjału społecznego [Malkowska 2014, s. 153-164]. Wraz ze zmieniającymi się funkcjami granic należy uwzględnić nowe kierunki ewolucji dotychczasowego modelu rozwoju tych obszarów.

Osiąganie takich celów, jak poprawa warunków życia ludności stref przygranicznych oraz podniesienie konkurencyjności gospodarek tych regionów, jest coraz częściej przedstawiane jako cele strategii wielofunkcyjnego rozwoju obszarów przygranicznych.

Dlatego też koncepcja rozwoju podkreślająca potrzebę budowania konkurencyjności w oparciu o multifunkcyjność społeczną i gospodarczą tych obszarów wydaje się szczególnie interesująca w kontekście rozwoju obszarów przygranicznych. Postrzega się obszary przygraniczne jako przestrzeń wielofunkcyjną, kształtowaną na nowo pod wpływem procesów globalizacyjnych, które prowadzą do powstawania i rozwijania nowych funkcji obszarów, takich jak turystyka medyczna.

\section{Turystyka medyczna w obszarach przygranicznych}

Rozwój wielofunkcyjny oznacza umiejętne wkomponowanie w przestrzeń gospodarczą licznych, często uzupełniających się funkcji, co korzystnie wpływa na zróżnicowanie społeczno-gospodarcze regionów peryferyjnych. Wdrożenie modelu zakładającego tworzenie nowych różnorodnych źródeł dochodów społeczności zamieszkujących obszary przygraniczne pozwala z jednej strony na poprawę jakości życia mieszkańców, a z drugiej strony determinuje dalszy proces poszukiwania nowych funkcji gospodarczych $\mathrm{w}$ regionie.

Jedną $\mathrm{z}$ takich nowych funkcji silnie rozwijających się w regionie zachodniego pogranicza Polski są usługi medyczne. Szczególnie interesujące ze względu na dynamikę procesu oraz potencjał rozwojowy jest zjawisko tzw. turystyki medycznej. Choć w ostatnim czasie ta specyficzna forma turystyki silnie się rozwija, to nadal nie doczekała się ona powszechnie obowiązujących definicji. Często przedstawiana jest ona jako jedna $\mathrm{z}$ trzech podstawowych form turystyki zdrowotnej, na którą składają się turystyka uzdrowiskowa, turystyka spa i wellness oraz turystyka medyczna [Gilnos i in. 2010, s. 1145-1155]. 
Turystyka medyczna dotyczy problematyki związanej z ruchem turystycznym między państwami, a także $w$ ramach poszczególnych państw. Rozpatrywana być może z punktu widzenia przyjeżdzających i wyjeżdżających. Jest coraz bardziej istotnym zjawiskiem społeczno-gospodarczym dla regionów przyjmujących medycznych turystów. Wśród wielu prób definicji tego zjawiska warto zwrócić uwagę na definicję Rab-Przybyłowicz [2010, s. 695], dla której turystyka medyczna dotyczy wyjazdów poza granice swojego regionu lub kraju, zaś motywem jest pobyt w gabinecie, klinice lub szpitalu w celu poprawy zdrowia bądź urody pod opieką lekarza specjalisty. Takie podejście do turystyki medycznej akcentuje fakt, że usługi medyczne, tak jak inne dobra, stały się przedmiotem wymiany, w tym wymiany międzynarodowej.

Turystyka medyczna rozpatrywana być może także jako forma minimalizacji ryzyka związanego z wykonywaniem specjalistycznych zabiegów medycznych poprzez dostęp do najlepszych specjalistów i terapii bez względu na poziom zabezpieczania medycznego w rodzimym kraju.

To także forma offshoringu usług medycznych [Kyoung-Hee, Levy 2010, s. 48, 758-783], z jednej strony polegająca na stworzeniu całego rynku obsługi turysty medycznego, a z drugiej może być rozpatrywana jako forma optymalizacji kosztów usług medycznych ponoszonych przez pacjentów [Kshetri, Dholakia 2011, s. 94-107]. Niewątpliwie jest zjawiskiem silnie związanym z procesami globalizacji i silną konkurencją na rynku usług medycznych, które same stają się globalne. Powoduje to rozwój placówek medycznych oferujących swoje usługi pacjentom z całego świata [Turner 2010, s. 443-467].

Warto jednak zauważyć, że według światowych rankingów dotyczących turystyki medycznej ocena usług medycznych w Polsce jest wysoka (tab. 1). Według rankingu z 2016 r., przeprowadzonego przez International Healthcare Research Center z siedzibą w Stanach Zjednoczonych, Polska plasuje się na 24 miejscu spośród 41 badanych krajów.

Tabela 1. Wartość Medical Tourism Index w 2016 roku

\begin{tabular}{|c|l|c|}
\hline Pozycja & \multicolumn{1}{|c|}{ Państwo } & Medical Tourism Index (ogólny) \\
\hline 1 & Kanada & 76,62 \\
\hline 2 & Wielka Brytania & 74,87 \\
\hline 3 & Izrael & 73,91 \\
\hline 4 & Singapur & 73,56 \\
\hline 5 & Indie & 72,10 \\
\hline 6 & Niemcy & $\mathbf{7 1 , 9 0}$ \\
\hline$\vdots$ & $\vdots$ & $\vdots$ \\
\hline 24 & Polska & $\mathbf{6 3 , 7 9}$ \\
\hline
\end{tabular}

Źródło: opracowanie własne na podstawie: https://www.medicaltourismindex.com (7.05.2017). 
Medical Tourism Index (MTI) to najczęściej cytowany wskaźnik turystyki medycznej w poszczególnych krajach świata [Fetscherin, Stephano 2016, s. 539-556]. Według ekspertów z branży medycznej, w rankingu znajdują się tylko te państwa, które w całościowej ocenie najczęściej rozważane są przez turystów medycznych jako miejsca warte uwagi pod względem turystyki medycznej.

Wysoka pozycja Niemiec $\mathrm{w}$ tym rankingu jest potwierdzeniem atrakcyjności tego kraju jako miejsca wykonywania usług medycznych także przez polskich pacjentów. $\mathrm{Z}$ kolei badania prowadzone na pograniczu polsko-niemieckim świadczą o rosnącej liczbie niemieckich turystów medycznych odwiedzających Polskę.

Globalizacja usług medycznych staje się we współczesnym świecie odpowiedzią na zwiększające się koszty opieki zdrowotnej w krajach wysokorozwiniętych. Alternatywą stają się usługi medyczne świadczone w krajach rozwijających się, oferujących często wysoki standard przy niższych cenach. Niższe koszty świadczeń medycznych za granicą są często wykorzystywane przez podmioty oferujące ubezpieczenia medyczne swoim klientom. Oferują one refundację kosztów świadczeń medycznych w krajach o niższych kosztach. Przykładem tego typu rozwiązań są umowy między niemieckimi kasami chorych a podmiotami świadczącymi usługi sanatoryjne i rehabilitacyjne w Polsce. Świnoujście, Kołobrzeg to polskie miejscowości uzdrowiskowe, które są wręcz nastawione na turystów z Niemiec.

Analizując wyniki badań w Polsce i innych krajach [Bookman, Bookman 2007; Horowitz, Rosensweig, Jones 2007, s. 33], można wskazać także szereg innych czynników, które zdaniem autora są istotne z punktu widzenia rozwoju turystyki medycznej w obszarach przygranicznych [Wismar i in. (ed.) 2008; Nakajima 2012]. Są to m.in.:

- wysoki koszt opieki zdrowotnej w krajach, z których pochodzą turyści medyczni,

- swoboda podróżowania, poprawa dostępności komunikacyjnej obszarów przygranicznych,

- nielegalność niektórych zabiegów medycznych, np. przerywania ciąży,

- zbyt długi czas oczekiwania na usługi medyczne turystów u siebie w kraju,

- możliwość skorzystania ze świadczeń dofinansowanych przez ubezpieczyciela.

Przeprowadzone badania wskazały na jeszcze jedną formę turystyki medycznej występującą w obszarze przygranicznym. Dotyczy ona osób, które pracują za granicą, ale oficjalnie mają status osoby bezrobotnej w Polsce. Do chwili wykreślenia z rejestru korzystają z bezpłatnej opieki zdrowotnej w Polsce mimo przebywania za granicą. W przypadku przyjazdu do Polski dokonują ponownej rejestracji w urzędzie pracy, co skutkuje możliwością korzystania z opieki zdrowotnej w Polsce, zazwyczaj do kolejnego wykreślenia z rejestru bezrobotnych w wyniku niepodjęcia pracy proponowanej przez urząd pracy.

Elementem turystyki medycznej jest także tzw. turystyka farmaceutyczna. Polega ona na podróży do innego kraju w celu zakupu tańszych bądź niedostępnych w swoim kraju leków [Lubowiecki-Vikuk, Mucha 2015, s. 147-156]. W przypadku 
zachodniego pogranicza Polski jest ona dość popularna w zakresie zaopatrzenia w farmaceutyki i parafarmaceutyki niedostępne w Polsce, a możliwe do kupienia w Niemczech. W szczególności dotyczy to środków medycznych dla dzieci np. Sab Simplex (środek na kolki dziecięce) czy specyfików homeopatycznych. Zważywszy na kierunek zmian w zakresie dostępu do antykoncepcji w Polsce, należy się spodziewać nasilenia tego zjawiska.

Rozwój turystyki medycznej w obszarach przygranicznych możliwy jest dzięki szybkiemu postępowi technicznemu i dyfuzji wiedzy i innowacji między ośrodkami medycznymi na całym świecie. Coraz większa dostępność do nowoczesnej aparatury diagnostycznej (tomograf komputerowy, rezonans magnetyczny), upowszechnienie międzynarodowych standardów i procedur leczenia, postępująca certyfikacja standardów świadczonych usług medycznych jest główną przyczyną rozwoju turystyki medycznej [Jarman, Greer 2010, s. 158-163].

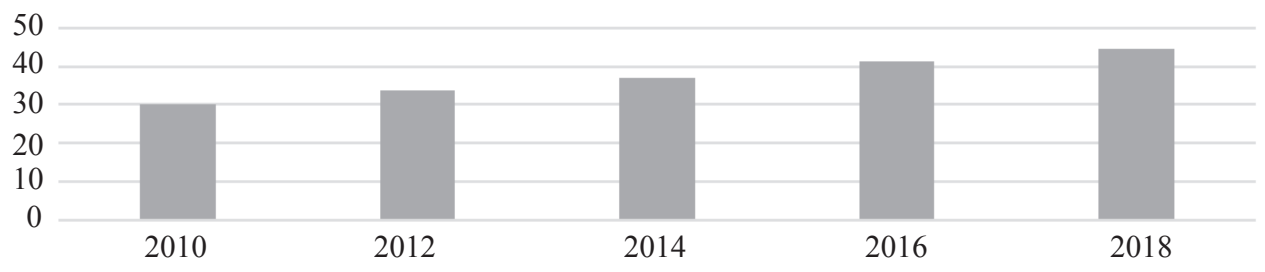

Rys. 1. Prognozowany wzrost wartości rynku usług medycznych w Polsce

Źródło: opracowanie własne na podstawie raportu firmy badawczej PMR: „Rynek prywatnej opieki zdrowotnej w Polsce 2014. Prognozy rozwoju na lata 2014-2018".

Co więcej, rynek usług medycznych ciągle należy do tych segmentów gospodarki, które pozwijają się najszybciej [Smith i in. 2011, s. 6]. Jak wskazano w raporcie „Rynek prywatnej opieki zdrowotnej w Polsce 2014. Prognozy rozwoju na lata 2014-2018", wartość rynku prywatnej opieki zdrowotnej w Polsce w 2013 roku wyniosła 35,4 mld zł, co stanowi wzrost w stosunku do roku poprzedniego o 4,6\%. Według prognoz do roku 2018 (zob. rys. 1), dynamika wzrostu powinna jeszcze przyspieszyć - całkowita wartość rynku ma około 46,7 mld zł na koniec 2018 roku (średnioroczny wzrost równy 5,7\%). W samym Szczecinie istnieją 3 renomowane kliniki chirurgii plastycznej, setki gabinetów stomatologicznych i protetycznych.

Wzrost zainteresowania obszarami przygranicznymi wśród inwestorów z branż medycznych związany jest także z nowymi możliwościami, które wprowadziła Komisja Europejska i unijna dyrektywa o transgranicznej opiece zdrowotnej. W jej myśl pacjent może skorzystać z zabiegu w innym kraju należącym do Unii Europejskiej, a następnie wystąpić do ubezpieczyciela o zwrot kosztów [Lach 2007, s. 9 i n.].

Turystyka medyczna to coraz bardziej popularna wśród Polaków forma leczenia. Świadczy o tym liczba wniosków kierowanych do Narodowego Funduszu Zdrowia, która systematycznie rośnie (w 2015 roku złożono 4874 wnioski na kwotę niemal 
18000000 zł, a w roku 2016 już 10632 wnioski na kwotę ponad 31000000 zł), a dotyczą one głównie zabiegowego leczenia zaćmy (ponad 90\% wniosków).

O ile dostępność zabiegów w ramach NFZ wpływa na coraz większą emigrację medyczną polskich pacjentów, o tyle rozwój wysokiej jakości prywatnej opieki zdrowotnej w Polsce sprawia, że do naszego kraju przyjeżdża wciąż więcej obcokrajowców. Najczęściej na leczenie do Polski decydują się pacjenci z krajów skandynawskich, Wielkiej Brytanii i Niemiec, rośnie też liczba pacjentów zza wschodniej granicy. Według danych firmy doradczej $\mathrm{PwC}$, do Polski każdego roku przyjeżdża niemal 400 tysięcy zagranicznych pacjentów którzy na pojedyncze zabiegi wydają nawet po 75 tysięcy złotych. Według szacunków Polskiego Stowarzyszenia Turystyki Medycznej wartość tego rynku wciąż rośnie - w 2015 roku zagraniczni pacjenci zostawili w polskich placówkach medycznych około 1,5 mld złotych.

Tabela 2. Porównanie cen popularnych zabiegów realizowanych w ramach turystyki medycznej

\begin{tabular}{|c|c|c|c|c|}
\hline $\begin{array}{r}\text { Rodzaj } \\
\text { zabiegu }\end{array}$ & $\begin{array}{l}\text { Usunięcie } \\
\text { migdałków }\end{array}$ & $\begin{array}{c}\text { Wstawienie stawu } \\
\text { biodrowego }\end{array}$ & $\begin{array}{l}\text { Operacja } \\
\text { żylaków }\end{array}$ & $\begin{array}{l}\text { Usunięcie } \\
\text { zaćmy }\end{array}$ \\
\hline Kraj & \multicolumn{4}{|c|}{ Ceny w zł } \\
\hline Polska & $1000-2200$ & $5500-25000$ & $650-2000$ & 2000 \\
\hline Czechy & $1900-2400$ & $13000-14000$ & 2100 & 1400 \\
\hline Słowacja & 1700 & $6800-18000$ & 1700 & 1616 \\
\hline Niemcy & 8600 & $5100-8900$ & 8800 & 5600 \\
\hline
\end{tabular}

Źródło: badania własne.

Wydaje się że spowodowane jest to przede wszystkim różnicami w cenach zabiegów (zob. tab. 2). Dotyczy to przede wszystkim chirurgii estetycznej i stomatologii.

\section{Zakończenie}

Współczesna gospodarka jest coraz bardziej zglobalizowana. Nikogo nie dziwią wyjazdy na zakupy do innego kraju czy spędzanie urlopu za granicą. Coraz częstszą formą aktywności społeczeństw jest turystyka medyczna. Wysoka mobilność współczesnych społeczeństw, dostępność komunikacyjna odległych nawet obszarów sprawia, że ta gałąź gospodarki dynamicznie się rozwija. Coraz wyższe standardy opieki w krajach o niższych kosztach zabiegów medycznych powodują wzrost zainteresowania tą formą aktywności turystycznej. Rozwój tej branży jest szczególnie widoczny na obszarze zachodniego pogranicza Polski. Dzięki rozwojowi turystyki medycznej zmienia się postrzeganie obszarów przygranicznych. Wysoka jakość usług w połączeniu z konkurencyjnymi cenami wpływa na zwiększenie liczby zagranicznych turystów medycznych w Polsce. Przeprowadzone badania wykazały prawdziwość postawionej na wstępie hipotezy badawczej. Turystyka medyczna jest ważnym czynnikiem rozwoju regionu. 
W przypadku województwa zachodniopomorskiego można już mówić o produkcie turystycznym związanym z usługami medycznymi. Prywatne kliniki, uzdrowiska, domy spokojnej starości są coraz częściej lokowane w strefie przygranicznej. Dzięki korzystnym przepisom, turystami medycznymi coraz częściej stają się mieszkańcy polskiej części pogranicza. To na nich czekają niemieckie kliniki z Prenzlau czy pobliskiego Berlina. Operacje zaćmy, zakupy leków w niemieckich aptekach stały się popularne wśród Polaków. Mieszkanki zachodniopomorskiego chcą rodzić swoje dzieci w klinice w Schwedt, a mieszkańcy Meklemburgii przyjeżdżają do Szczecina na zabiegi chirurgii estetycznej. To jeden z wymiarów zintegrowanego regionu transgranicznego, w którym turystyka medyczna odgrywa coraz większą rolę.

\section{Literatura}

Bookman M., Bookman K., 2007, Medical Tourism in Developing Countries, Springer, New York.

Cross - Border Health Services in the EU. Analytical Report. The Gallup Organization, Flash EB nr 210, June 2007.

Fetscherin M., Stephano R.M., 2016, The medical tourism index: Scale development and validation, Tourism Management, 52, s. 539-556.

Gilnos I.A., Baeten R., Helble M., Maarse H., 2010, A typology of cross-border patient mobility, Health \& Place, 16, s. 1145-1155.

Horowitz M.D., Rosensweig J.A., Jones C.A., 2007, Medical tourism: globalization of the healthcare marketplace, MedGenMed, 9(4).

http://www.medicaltourismassociation.com/en/medical-tourism-faq-s.html.

Jarman H., Greer S., 2010, Cross-border trade in health services: Lessons from the European Laboratory, Health Policy, 94 (2), s. 158-163.

Kłodziński M., 1995, Wielofunkcyjny rozwój obszarów wiejskich na pograniczu polsko-niemieckim, Zeszyty Naukowe Akademii Rolniczej w Krakowie. Sesja Naukowa, nr 43, s. 115-121.

Kłodziński M., Okuniewski J., 1993, Wielofunkcyjny rozwój obszarów wiejskich na terenach przygranicznych. Studium na przykładzie gminy Myślibórz, IRWiR PAN, SGGW, Warszawa.

Krok K., 2006, Wspótczesne spojrzenie na obszary przygraniczne w Europie, [w:] Gorzelak G., Krok K. (red.), Nowe granice Unii Europejskiej - wspólpraca czy wykluczenie, Scholar, Warszawa.

Kshetri N., Dholakia N., 2011, Offshoring of Healthcare Services: the case of US - India trade in medical transcription ser-vices, Journal of Health Organization and Management, 25 (1), s. 94-107.

Kyoung-Hee Y., Levy F., 2010, Offshoring professional services: Institutions and professional control, British Journal of Industrial Relations, 48, issue 4, s. 758-783.

Lach D.E., 2007, Spetnianie świadczeń zdrowotnych na terytorium UE - kolejki a ,turystyka zdrowotna" w świetle orzecznictwa ETS, Praca i Zabezpieczenie Społeczne, $\mathrm{nr} 5$.

Lubowiecki-Vikuk A., Mucha D., 2015, Perspektywy rozwoju turystyki farmaceutycznej w regionie Polski południowej, Rozprawy Naukowe Akademii Wychowania Fizycznego we Wrocławiu, nr 49, s. 147-156.

Malkowska A., 2014, Wzmacnianie kapitału społecznego regionu przygranicznego na przykładzie województwa zachodniopomorskiego. Rola kapitału ludzkiego w rozwoju społeczno-gospodarczym regionu, Zeszyty Naukowe Uniwersytetu Szczecińskiego. Ekonomiczne Problemy Usług, nr 114, s. $153-164$. 
Malkowski A., 2011, Regiony przygraniczne jako terytoria peryferyjne na przyktadzie wschodniego i zachodniego pogranicza, Prace Naukowe Uniwersytetu Ekonomicznego we Wrocławiu, nr 221, s. $364-372$.

Malkowski A., 2013, Wschodnia granica Polski. Od peryferii i izolacji do wspótdziałania, Prace Naukowe Uniwersytetu Ekonomicznego we Wrocławiu, nr 307, s. 363-372.

Miszczuk A., 2013, Uwarunkowania peryferyjności regionu przygranicznego, Norbertinum, Lublin.

Nakajima I., 2012, Cross-border medical care and telemedicine, International Journal of E-Health and Medical Communications, no. 3, s. 46-61.

Prochorowicz M., 2008, Turystyka medyczna nowa perspektywa dla polskich placówek stużby zdrowia, [w:] Grzywacz R. (red.), Turystyka i rekreacja szansa rozwoju aktywności społecznej, Wyd. WWSiZ, Rzeszów.

Przybyła Z., 1995, Problemy wspótpracy ekonomicznej regionów przygranicznych (na przykładzie euroregionu Nysa), Prace Naukowe Akademii Ekonomicznej we Wrocławiu. Seria: Monografie i Opracowania, nr 100.

Rab-Przybyłowicz J., 2010, Tworzenie produktu dla turystyki medycznej w Szczecinie. Potencjat turystyczny - zagadnienia ekonomiczne, Zeszyty Naukowe Uniwersytetu Szczecińskiego, nr 591, Ekonomiczne Problemy Usług, nr 53.

Sammel A., Prochorowicz M., Majewska D., 2013, Rola turystyki w zrównoważonym rozwoju gmin przygranicznych województwa zachodniopomorskiego, Europa Regionum, nr 16.

Smith R., Exworthy M., Green S., Horsfall D., Mannion R., 2011, Medical Tourism: Treatments, Markets and Health System Implications: A Scoping Review, OECD, Paris.

Turner L., 2010, "Medical tourism" and the global marketplace in health services: US patients, international hospitals, and the search for affordable health care, International Journal of Health Services, $\mathrm{nr}$ 40(3), s. 443-467.

Wismar M., Palm W., Figueras J., Ernst K., Ginneken E. van (ed.), 2008, Cross - Border Health Care in the European Union. Mapping and Analysing Practices and Policies, European Observatory on Health Systems and Policies, Copenhagen. 